\title{
Surveillance of Post-operative Wound Infections Along with their Bacteriological Profile and Antibiotic Sensitivity Pattern at Government Cancer Hospital, Aurangabad, India
}

\author{
Nazneen Siddiqui*, Somnath Nandkar, Mukta Khaparkuntikar and Arvind Gaikwad \\ Department of Microbiology, Government Cancer Hospital, Opp Aamkhaas Maidan, \\ Aurangabad, M.S.431001, India \\ *Corresponding author
}

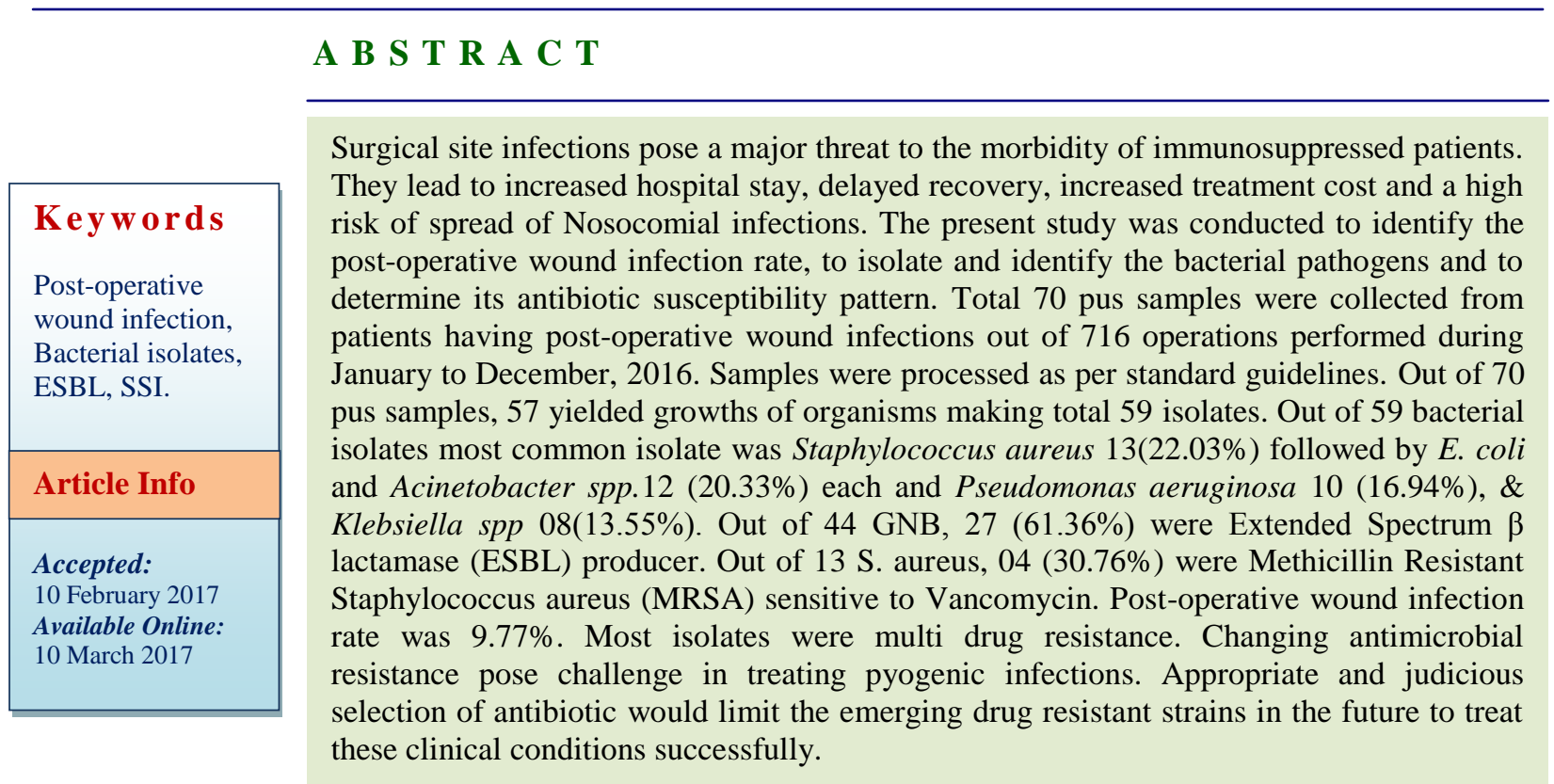

\section{Introduction}

Infection is the clinical manifestation of the inflammatory reaction incited by invasion and proliferation of micro-organisms (Abdul et $a l .$,$) . Despite modern surgical techniques and$ the use of antibiotic prophylaxis, surgical site infection (SSI) is one of the most common complications encountered in surgery (Mehta et al., 2013). A surgical site infection is an infection that occurs after surgery in the part of the body where the surgery took place [CDC Healthcare-associated Infections (HAI)]. Surgical site infections (SSIs) are defined as infections occurring up to 30 days after surgery (or up to one year after surgery in patients receiving implants) and affecting either the incision or deep tissue at the operation site (Owens et al., 2008). Surgical site infections are third most commonly reported nosocomial infection \& they account for approximately a quarter of all nosocomial infections. They have been responsible for increasing cost, morbidity and mortality related to surgical operations and continues to be a major problem even in hospitals with 
most modern facilities \& standard protocols of preoperative preparation and antibiotic prophylaxis.

Reported surgical site infection rate in India has varied from a low of $2.5 \%$ to a high of $41.9 \%$ over a period of decades .The increasing number of immunocompromised patients and increased use of indwelling devices, as well as widespread use of antimicrobial agents in hospital settings, particularly in intensive care units (ICUs), contributes to antimicrobial resistance among pathogens causing nosocomial infections (Asfia et al., 2015).

Surveillance of post-operative wound infections helps in determining the infection rates, risk factors and in planning the preventive strategies to ensure a quality healthcare in hospital (Bemnet et al., 2011).

Since ours is a newly constructed 100 bedded Cancer hospital, it is very necessary for us to keep a check on Hospital Associated infections from an early stage so that we can analyse and apply preventive measures required to keep these infection rates to their minimum. Hence we conducted this study to measure the post- operative wound infection rate and to isolate and identify the bacterial pathogens and to determine its antibiotic susceptibility pattern.

\section{Materials and Methods}

The present study was conducted in the Department of Microbiology, Government Cancer Hospital, Aurangabad during one year period from January to December, 2016. Out of 716 total operations performed, $70(9.41 \%)$ patients having post- operative surgical site infections were included in the study.

Sample collection: Pus samples were collected from surgical site wound infections, using a sterile disposable swab. Care was taken to avoid contamination. Swabs were transported to the Microbiology laboratory and processed as per standard guidelines. Isolates were identified morphologically and confirmed by biochemical reaction (Koneman et al., 2006; Forbes et al., 2007).

Criteria for antimicrobial sensitivity testing were carried out as per Clinical Laboratory standard institute (CLSI). Antimicrobial sensitivity testing was done on Muller Hinton Agar (MHA) by Kirby Bauer's disc diffusion method (CLSI, 2016). Commercially available discs (Hi-media) were used. For Gram-positive organisms, the antibiotics to be tested and reported were chosen from the following (depending on the organism isolated): Penicillin (10 units), Erythromycin $(15 \mu \mathrm{g})$, Clindamycin $(2 \mu \mathrm{g})$, Gentamicin (10mcg) \& high level (30mcg), Amoxicillinclavulanate $(20 / 10 \mu \mathrm{g})$, Cefoxitin $(30 \mu \mathrm{g})$, Levofloxacin $(5 \mu \mathrm{g}), \quad$ Vancomycin $(30 \mu \mathrm{g} / \mathrm{MIC})$, Linezolid $(30 \mu \mathrm{g})$, and Cotrimoxazole $(1.25 / 23.75 \mu \mathrm{g})$.

For Gram-negative, the antibiotics for respective organisms were chosen from the following: Ciprofloxacin $(5 \mu \mathrm{g})$, Levofloxacin $(5 \mu \mathrm{g})$, Norfloxacin $(5 \mu \mathrm{g})$, Gentamicin (10 $\mu \mathrm{g})$, Amikacin $(30 \mu \mathrm{g})$, Cefpodoxime $(30 \mu \mathrm{g})$, Cefotaxime $(30 \mu \mathrm{g})$, Ceftazidime $(30 \mu \mathrm{g})$, Cefepime $(30 \mu \mathrm{g})$, Piperacillin+Tazobactum (100/10mcg), Imipenem (10 $\mu \mathrm{g})$, and Colistin.

Methicillin resistance in Staphylococcus aureus (MRSA) was tested using Muller Hinton Agar with Cefoxitin disc (30 mcg) by Kirby-bauer disc diffusion methods as per CLSI guidelines. Suspected extendedspectrum beta lactamases (ESBLs) producing Enterobactericae were confirmed by double disk synergy test as per CLSI guidelines.

Staphylococcus aureus (ATCC 25923), E. coli (ATCC 25922) and P. aeruoginosa 
(ATCC 27853) were used as quality control throughout the study for culture and antimicrobial susceptibility testing.

\section{Results and Discussion}

$70(9.77 \%)$ pus samples were obtained out of 716 operations performed. Out of 70 pus samples received for culture and sensitivity in the microbiology central laboratory, 57 $(89.47 \%)$ cases yielded positive culture while $13(10.53 \%)$ cases had no growth (Figure-1). Among the 57 culture positive pus samples, 55 yielded pure bacterial isolates and 2 yielded mixed infection, so a total number of 59 organisms were isolated out of 70 pus samples. Out of 59 bacterial isolates, 44 were Gram negative bacilli (GNB) and 15 Were Gram positive cocci (GPC). Most common bacteria isolated were Staphylococcus aureus $13(22.03 \%)$ followed by $E$. coli and Acinetobacter spp.12 (20.33\%) each and Pseudomonas aeruginosa 10(16.94\%) \&
Klebsiella spp. 08 (13.55\%) (Table 1). Among the Gram Negatives the most prevalent organisms isolated were $E$. coli (27.27\%) and Acinetobacter spp. (27.27\%) followed by Pseudomonas species $(22.72 \%)$ and Klebsiella (18.18\%) and Other organisms isolated were Proteus and Serratia 01each (Table 2). Among the Gram positives the most prevalent organisms isolated were Staphylococcus aureus (86.66) followed by Enterococcus spp (13.33\%) (Table 3)

Out of 44 Gram negative isolates, 27 $(61.36 \%)$ were Extended Spectrum $\beta$ lactamase (ESBL) producer. Resistance to Carbapenems was highest among Klebsiella (37.5\%) followed by Acinetobacter spp. (33.33\%) and Pseudomonas (30\%).Refer Table 4 and 5 for detailed antibiogram of GNB and GPC resp. Out of 13 S. aureus, 04 $(30.76 \%)$ were Methicillin Resistant Staphylococcus aureus (MRSA) and sensitive to Vancomycin.

Table.1 Bacterial profile of pus culture

\begin{tabular}{|l|l|l|l|}
\hline Sr. No & Organism & Number & \% \\
\hline $\mathbf{1 .}$ & $\begin{array}{l}\text { Staphylococcus } \\
\text { aureus }\end{array}$ & $\mathbf{1 3}$ & $\mathbf{2 2 . 0 3 \%}$ \\
\hline $\mathbf{2 .}$ & E. coli & $\mathbf{1 2}$ & $\mathbf{2 0 . 3 3 \%}$ \\
\hline $\mathbf{3 .}$ & Acinetobacter spp. & $\mathbf{1 2}$ & $\mathbf{2 0 . 3 3 \%}$ \\
\hline $\mathbf{4 .}$ & $\begin{array}{l}\text { Pseudomonas } \\
\text { aeruginosa }\end{array}$ & $\mathbf{1 0}$ & $\mathbf{1 6 . 9 4 \%}$ \\
\hline $\mathbf{5 .}$ & Klebsiella spp. & $\mathbf{0 8}$ & $\mathbf{1 3 . 5 5 \%}$ \\
\hline $\mathbf{6 .}$ & Enterococci spp. & $\mathbf{0 2}$ & $\mathbf{3 . 3 8 \%}$ \\
\hline
\end{tabular}

Table.2 Gram negative isolates (n-44).

\begin{tabular}{|c|l|c|c|}
\hline Sr.No. & \multicolumn{1}{|c|}{$\begin{array}{c}\text { Gram negative } \\
\text { isolates }\end{array}$} & Total numbers & Percentage\% \\
\hline 1. & E. coli & 12 & $27.27 \%$ \\
\hline 2. & Acinetobacter spp & 12 & $27.27 \%$ \\
\hline 3. & $\begin{array}{l}\text { Pseudomonas } \\
\text { aeruginosa }\end{array}$ & 10 & $22.72 \%$ \\
\hline 4. & Klebsiella spp & 08 & $18.18 \%$ \\
\hline 5. & Others & 02 & $4.54 \%$ \\
\hline
\end{tabular}

Others-Proteus and Serratia. 
Table.3 Gram positive isolates (n-15)

\begin{tabular}{|c|l|c|c|}
\hline Sr. No. & Gram positive isolates & $\begin{array}{c}\text { Total } \\
\text { numbers }\end{array}$ & Percentage \\
\hline 1. & Staphylococcus aureus & 13 & $86.66 \%$ \\
\hline 2. & Enterococci spp & 02 & $13.33 \%$ \\
\hline
\end{tabular}

Table.4 Resistance to antibiotics among common Gram negative isolates (\%)

\begin{tabular}{|r|l|c|c|c|c|c|c|}
\hline $\begin{array}{c}\text { Sr. } \\
\text { No. }\end{array}$ & \multicolumn{1}{|c|}{$\begin{array}{c}\text { Gram } \\
\text { negative } \\
\text { isolates }\end{array}$} & $\begin{array}{c}\text { Amino } \\
\text { glycosides }\end{array}$ & $\begin{array}{c}\text { Fluoro } \\
\text { quino } \\
\text { lones }\end{array}$ & $\begin{array}{c}\mathbf{3}^{\text {rd }} \\
\text { Generation } \\
\text { Cephalo } \\
\text { sporins }\end{array}$ & $\begin{array}{c}\text { Piperacillin+ } \\
\text { tazobactam }\end{array}$ & Cefepime & Imepenem \\
\hline 1. & E.coli & 66.6 & 66.6 & 76.6 & 41.6 & 50 & 16.6 \\
\hline 2. & $\begin{array}{l}\text { Acinetobacter } \\
\text { spp }\end{array}$ & 83.3 & 91.6 & 83.3 & 58.33 & 50 & 33.3 \\
\hline 3. & Klebsiellaspp & 75 & 87.5 & 75 & 50 & 62.5 & 37.5 \\
\hline 4. & $\begin{array}{l}\text { Pseudomonas } \\
\text { aeruginosa }\end{array}$ & 40.0 & 60.0 & 60.0 & 2530.0 & 50 & 30.0 \\
\hline
\end{tabular}

Table.5 Antibiogram of Staphylococcus aureus

\begin{tabular}{|c|c|c|}
\hline Name of Antibiotic & Staphylococcus aureus N=13 & \\
\hline & $\mathbf{R}$ & $\mathbf{S}$ \\
\hline Erythromycin & $61.53 \%$ & $38.47 \%$ \\
\hline Clindamycin & $38.46 \%$ & $61.54 \%$ \\
\hline Fluoroquinolones & $61.53 \%$ & $38.47 \%$ \\
\hline Cefoxitin & $30.76 \%$ & $69.24 \%$ \\
\hline Amoxy-Clav & $53.84 \%$ & $46.16 \%$ \\
\hline Linezolid & $0 \%$ & $100 \%$ \\
\hline Cotrimoxazole & $59.28 \%$ & $40.72 \%$ \\
\hline Vancomycin & $0 \%$ & $100 \%$ \\
\hline
\end{tabular}

Fig.1 Pie chart showing culture positivity among pus sample

\section{Culture \\ positive \\ $81 \%$}


According to WHO guidelines of hospital acquired infections, Surgical Site Infection contributes to $0.5 \%$ to $15 \%$ of total burden to HAI. In our study, 70 (9.7\%) cases developed SSI, this finding was consistent with findings of Mehta et al., (2013) and Asfia et al., (2015). Similar rates were obtained by Varsha et al., (2012) and Sule et al., (2002). Other studies Khalid et al., (2010) and Mohammed et al., (2013) have reported quite a high incidence of SSI. In the present study $S$. aureus $(22.3 \%)$ was the most common isolate which is comparable with Mehta et al., (2013), Chauhan et al., (2015) and Raghav et al., (2014). The second most common organism isolated in our study was $E$. coli and Acinetobacter spp. (20.33\%). Similar results with E. coli were also seen by Chauhan et al., (2015) and Basu et al., (2009). A study conducted at Karnataka (Kapoor et al., 2014) has shown similar prevalence of Acinetobacter (22.2\%). Overall, there has been an increase in the prevalence of multi drug resistant organisms (MDRO) in the last decade globally, which is much more in India compared to Western populations (Basu et al., 2009). Our study showed a very high percentage of resistance among organisms to betalactam antibiotics, combination of betalactam/ betalactamase inhibitors. Of major concern was the observation that there was a very high prevalence of ESBL among the GNB's (61.36\%). Same trend was observed by Kapoor et al., (2014) and Mathur et al., (2002).

Resistance to carbapenems was seen to be prevalent in Klebsiella (37.5\%) followed by Acinetobacter spp $(33.33 \%)$ and Pseudomonas (30\%), the resistance to carbapenems at our institute was lower than that seen by Vivek et al., (2016), but higher than the findings depicted by Santosh et al., (2016). The problem of antibiotic resistance is fortunately not as high among the Grampositive organisms. We did not encounter any vancomycin resistance among staphylococci, and MRSA rates have been approximate $30.76 \%$ which was comparable to other studies.

In conclusion, SSI causes considerable morbidity among surgical patients. In Cancer patient's immunosuppression can play a major role in developing these infections. Appropriate active surveillance and infection control measures should be introduced during preoperative, intra-operative, and postoperative care to reduce infection rates. Irrational use of antibiotics should be stopped. Our ability to successfully treat infections due to these increasingly resistant organisms demands a multifactorial approach combining continued research and development of novel classes of antibacterial agents, more prudent use of existing agents and an increased emphasis on more effective infection control measures.

\section{References}

Abdul, R., Nair, A. Textbook of Surgery, 11th ed. Surgical Site Infect., 16: 98-102.

Asfia Sultan, Meher Rizvi, Fatima Khan, Sana Ali, Indu Shukla, Abidakhatoon. Incidence of surgical site infections, their etiology, associated antimicrobial use and antimicrobial resistance in a tertiary care centre in northern India Ejpmr, 2(7): 347352.

Basu, S., Ramchuran Panray, T., Bali Singh, T., Gulati, A.K., Shukla, V.K. 2009. A; Prospective, descriptive study to identify the microbiological profile of chronic wounds in outpatients. Ostomy Wound Manage, 55(1): 14-20.

Bemnet, A., Zeki, A., Beyne, M. 2011. Postoperative Surgical Site Bacterial infections and drug Susceptibility Patterns at Gondar University Teaching Hospital, Northwest Ethiopia. J. Bacteriol. Parasitol., 2(8). 
CDC Healthcare-associated Infections (HAI) Types of Infections. Surgical Site Infection (SSI).

Chauhan, M., Manish, S. and S. Mahajan. 2015. Aerobic Bacterial Profile and antibiotic sensitivity pattern of pusisolates in a tertiary care Hospital. Int. J. Curr. Microbiol. App. Sci., 4(5): 784-787.

CLSI-Clinical and Laboratory Standards Institute 2016. Performance standards for antimicrobial susceptibility testing. Twenty-second informational supplement. Wayne, PA, USA.

Forbes, B.A., Sahm, D.F., Weissfeld, A.S. 2007. In: Bailey and Scott's Diagnostic Microbiology. 12th ed. Missouri: Mosby Elsevier; p. 779.

Kapoor, G., Sachdeva, N., Jain, S. 2014. Epidemiology of bacterial isolates among pediatric cancer patients from a tertiary care oncology center in North India. Indian $J$. Cancer, 51: 420-4.

Khaleid, M., Ibraheim, Z. 2010. Surgical Site Infections and Associated Risk Factors in Egyptian Orthopedic Patients, Amer. J. Sci., 6(7).

Koneman, E.W., Allen, S.D., Janda, W.M., Schreckember, P.C., Winn, W.C. 2006. Koneman's Colour Atlas and text book of Diagnostic Microbiology. 6th edition. Newyork: Lippincott, 97-99.

Kotgire Santosh, A., Sunil Hatkar, S., Sufia Siddique, A.B., Deshmuk, et al. 2016. Bacteriological Profile and Antimicrobial Sensitivity Pattern of Clinical Isolates from Patients Attending Tertiary Care Hospital. Annals of Pathol. Lab. Med., Vol. 03, No. 04.
Mathur, P., Kapil, A., Das, B., Dhawan, B. 2002. Prevalence of extended spectrum beta lactamase producing Gram negative bacteria in a tertiary care hospital. Indian J. Med. Res., 115: 153-7.

Mehta, V.J., Pandya, J.M., Mehta, S.J. 2013. Surveillance of post-operative wound infections in a Teaching Hospital, Gujarat. Int. J. Res. Med., 2(4): 77-79.

Mohammed, A., Adeshina, G.O. and Ibrahim, Y.K.E. 2013. Retrospective incidence of wound infections and antibiotic sensitivity pattern: A study conducted at the Aminu Kano Teaching Hospital, Kano, Nigeria. Int. J. Med. Med. Sci., 5(2): 60-6.

Owens, C.D., Stoessel, K. 2008. Surgical site infections: epidemiology, microbiology and prevention. J. Hosp. Infect., 70Suppl 2: 310. doi: 10.1016/S0195-6701(08)60017-1.)

Shahane, V., Bhawal, S. 2012. Surgical site infections: A one year prospective study in a tertiary care center. Int. J. Health Sci., 6(1): 79-84.

Sule, M. 2002. Bacterial pathogens associated with infected wounds in a teaching hospital, AFR J. Clin. Exp. Microbiol., 3(1): 13-16.

Tiwari, P., Kaur, S. 2010. Profile and sensitivity pattern of bacteria isolated from various cultures in a Tertiary Care Hospital in Delhi. Indian J. Public Health, 54(4): 2135.

Vivek Bhat, Sudeep Gupta, RohiniKelkar, Sanjay Biswas, NavinKhattry, AliasgarMoiyadi, Prashant Bhat et al. 2016. Bacteriological profile and antibiotic susceptibility patterns of clinical isolates in a tertiary care cancer center. Indian J. Med. Paediatr. Oncol., 37(1): 20-24.

\section{How to cite this article:}

Nazneen Siddiqui, Somnath Nandkar, Mukta Khaparkuntikar and Arvind Gaikwad. 2017. Surveillance of Post-operative Wound Infections Along with their Bacteriological Profile and Antibiotic Sensitivity Pattern at Government Cancer Hospital, Aurangabad, India. Int.J.Curr.Microbiol.App.Sci. 6(3): 595-600. doi: https://doi.org/10.20546/ijcmas.2017.603.069 